\title{
The Impact of Business Process Orientation on Organizational Performance
}

\author{
Rok Škrinjar and \\ Mojca Indihar Štemberger \\ University of Ljubljana, \\ Faculty of Economics \\ Ljubljana, Slovenia \\ rok.skrinjar@ef.uni-lj.si \\ mojca.stemberger@ef.uni-li.si
}

\author{
Tomislav Hernaus \\ University of Zagreb, \\ Faculty of Economics \\ Zagreb, Croatia
}

\begin{abstract}
The extensive literature on business process management suggests that organizations can enhance their overall performance by adopting a process view of business. It has been shown in previous studies that the companies which have reached higher business process maturity level consistently outperform those that have not reached them. The paper presents the results of the empirical research that confirms the impact of business process orientation on organizational performance in transition economy by using structural equation modeling. The link is even stronger than in the original investigation. Besides that more detailed specification of organizational performance that includes non-financial performance measures has been used. The results show that business process orientation leads to better non-financial performance and indirectly to better financial performance.
\end{abstract}

Keywords: business process orientation, organizational performance, non-financial performance, business process management, structural equation modeling

\section{Introduction}

Organizations are continually under competitive pressures and forced to re-evaluate their business models and underlying business processes. Business processes represent a core of the functioning of an organization because the company primarily consists of processes, not products or services. In other words, managing a business means managing its processes (McCormack \& Johnson, 2001). Despite their importance, the business processes have been neglected for a long time in managerial studies mainly due to the fact that departments in companies are structured in a functional or product oriented way.

Material published as part of this publication, either on-line or in print, is copyrighted by the Informing Science Institute. Permission to make digital or paper copy of part or all of these works for personal or classroom use is granted without fee provided that the copies are not made or distributed for profit or commercial advantage AND that copies 1) bear this notice in full and 2) give the full citation on the first page. It is permissible to abstract these works so long as credit is given. To copy in all other cases or to republish or to post on a server or to redistribute to lists requires specific permission and payment of a fee. Contact Publisher@InformingScience.org to request redistribution permission.
The extensive literature on business process management (e.g. Davenport, 1993; Hammer \& Champy, 1993; McCormack \& Johnson, 2001; Burlton, 2001; Harmon, 2003) suggests that organizations can enhance their overall performance by adopting a process view of business. Most of the literature on business process management lacks research or an empirical focus (McCormack, 1999). However, McCormack and 
Johnson (2001) showed that business process orientation has positive impact on business performance.

Based on the original study a joint empirical research by Faculty of Economics in Ljubljana and Zagreb was carried out in Slovenia. The aim was to investigate the understanding of the process view and process maturity levels of Slovenian companies and to test the impact of process orientation maturity level on organizational performance. The paper presents the results of the empirical research that confirms the impact of business process orientation on organizational performance. While a similar research has been carried out by McCormack and Johnson (2001) our contribution is the verification of the link in transition economy and more detailed specification of organizational performance that includes non-financial performance measures.

The paper is structured as follows. The next section reviews the relevant literature about business process orientation, organizational performance and the link between the two concepts. In the third section the research model is conceptualized and suitable hypotheses are developed. Section 4 aims to present a methodological framework for the study and provides results of data analysis. Section 5 concludes with a summary of the main findings, discusses them from theoretical and practical standpoints, and outlines directions for future research together with the limitations of the study.

\section{Literature Review}

\section{Business Process Orientation (BPO)}

The competitive global market climate of the new millennium has raised awareness of business processes as the most important management paradigm. The idea of the process organization is gaining strong momentum; the process 'option' is now becoming a mandatory requirement (Levi, 2002). In other words, in conformity with new business philosophy, the organization should be designed to provide both vertical and horizontal information flow as necessary to accomplish the organization's overall goals (Daft, 2004). Looking beyond functional boundaries, business processes emerge - the way business actually works becomes clear. Moreover, firm's performance is visualized in the efficiency of its processes, what demands a process orientation.

Process orientation still isn't recognized as an independent discipline, it rather represents a generic concept of numerous management philosophies which use process perspective to improve business performance (Lindfors, 2003). Although empirical evidence is lacking, several models have emerged during the last few years that have been presented as the high performance, process-oriented organization needed in today and tomorrow's world. Deming, Porter, Davenport, Short, Hammer, Byrne, Imai, Drucker, Rummler-Brache and Melan have all defined what they view as the new model of the organization. This "new way of thinking" or "viewing" the organization has been generally described as business process orientation or BPO (McCormack and Johnson, 2001).

Although definitions of the business process orientation vary, we adopt the McCormack's and Johnson's (2001) definition of process orientation: An organization that, in all its thinking, emphasizes process as opposed to hierarchies with a special emphasis on outcomes and customer satisfaction. However, business process orientation should be distinguished from a process-based organizational structure concept. It represents the understanding of the business flow, and it is only the first step toward such organizational form. On the other hand, it can be viewed as a broader term than the process organization, because an organization can reach a certain degree of BPO maturity without formally being organized horizontally (Kai, 1999). 
It becomes evident that all organizations are compounds of business processes, although they do not have a process view. However, a process approach can be applied on each organization. Congruently, for them it could be determined a level of process orientation with respect to business performance. Levels of process orientation are often presented by process maturity concept. In the current business environment, there is no scarcity of process maturity models. For the purpose of this research the BPO maturity model was readjusted from K. P. McCormack and C. W. Johnson (2001). The original model was developed based on the concepts of process maturity, BPO, and the Capability Maturity Model developed by the Software Engineering Institute at Carnegie Mellon University (Lockamy III \& McCormack, 2004). The BPO construct describes a four-step pathway for systematically advancing business processes along the maturity continuum (Ad Hoc, Defined, Linked, and Integrated level). Each step builds on the work of the previous steps to apply improvement strategies that are appropriate to the current maturity level. The following definitions for the stages that an organization goes through when becoming business process oriented are provided:

- Ad Hoc: The processes are unstructured and ill defined. Process measures are not in place and the jobs and organizational structures are based upon the traditional functions, not horizontal processes.

- Defined: The basic processes are defined and documented and are available in flow charts. Changes to these processes must now go through a formal procedure. Jobs and organizational structures include a process aspect, but remain basically functional. Representatives from functional areas (sales, manufacturing, etc.) meet regularly to coordinate with each other, but only as representatives of their traditional functions.

- Linked: The breakthrough level. Managers employ process management with strategic intent and results. Broad process jobs and structures are put in place outside of traditional functions.

- Integrated: The company, its vendors and suppliers, take cooperation to the process level. Organizational structures and jobs are based on processes, and traditional functions begin to be equal or sometimes subordinate to process. Process measures and management systems are deeply imbedded in the organization. (McCormack \& Johnson, 2001; McCormack, 2003).

Except aggregate level, the BPO construct is contained from following individual dimensions: process view, process jobs, process management and measurement. Process view involves a focus on the workflows and processes across the organization. The goal is to get as much as possible out of the process and not of the individual person (Häggström \& Oscarsson, 2001). It is instructive because it follows work as it proceeds across the organization. Perhaps even more important, functional roles and titles reflecting the traditional hierarchical structure are replaced by process owners - leaders who are responsible and accountable for the operation and improvement of the core business (Tenner \& DeToro, 1996). Along with process owners, process teams become the main building element of organization which emphasizes the process job category. Finally, process management, supplemented with process measures, is as much to do with changing the culture and the way of thinking, as it is to do with changing the organizational structure. It is this most fundamental aspect of the transition that the majority of organizations have failed to appreciate (O'Hanlon, 2003). Neumann et al. see the main task of process management in accompanying the process implementation, and ensuring the continuous, incremental improvement of the organization's processes (zur Muehlen, 2002). 


\section{Organizational Performance}

The corporate world has historically measured financial performance and sales volume. Measures of financial performance, sales volume, and customer satisfaction are not wrong: they are merely insufficient. Many organizations fail to understand how these indicators fit within the comprehensive measurement strategy that is required to effectively redesign processes (Tenner \& DeToro, 1996).

An increasing number of academics are now extolling the central role of business processes in improving performance. Most recently, Kaplan and Norton's book "Strategy Maps: Converting Intangible Assets into Tangible Outcomes" places business processes at the centre of their approach of measuring a firm's progress in implementing strategy (Spanyi, 2004a). They wanted to emphasize that in a process of moving to a process enterprise, therefore, managers need to conduct a thorough analysis to determine what aspects of process performance are most directly linked to achieving the organization's overall objectives (Hammer and Stanton, 2001).

However, while both process definition and measurement is important, in themselves they are not sufficient to assure performance improvement. Assessing process competence needs to address the extent to which enterprise level business processes are defined, measured, improved and managed. The selected model must explicitly recognize that process competence at the enterprise level involves a combination of aptitude in improving and managing the firm's large crossfunctional business processes and leadership attitude in measuring and managing the firm's activities in business process terms. The selected model should facilitate either self assessment by a cross-functional team or assessment by an external party. This means that the model should be both sufficiently robust to capture a snapshot of the organization's current performance and be sufficiently streamlined to permit repeated application at the enterprise and division level. Ideally, the selected model should be designed such that it facilitates a comparison of the firm's performance to industry standards for the majority of the enterprise processes (Spanyi, 2004b).

From the following a main characteristic of today's business environment could be recognized the increasing importance and strength of various stakeholder groups. Namely, businesses realized the importance of a multidimensional and balanced performance measurement system as a tool that would enable them to drive the company forward. It is now widely accepted that the use of appropriately defined measures can ensure the strategic alignment of the organization and communication of the strategy throughout the business (Najmi, Rigas, \& Fan, 2005). Taking the concept a bit further, Andersson et al. (1989), Eccles (1991), Lynch and Cross (1991) and Kaplan and Norton (1992) identified the weaknesses of traditional measurement systems because of their uni-dimensional and backward looking nature. This led to the development of innovative performance measurement frameworks which viewed business performance through more than one perspective. (Najmi, Rigas, \& Fan, 2005)

The stakeholder view (main idea arose from Freeman's Stakeholder Theory, e.g. see Freeman $(1984,1994)$ ) maintains that firms have stakeholders rather than just shareholders to account for. The view that the corporation has obligations only to its stockholders is replaced by the notion that there are other groups to whom the firm is also responsible. Groups with a 'stake' in the firm include shareholders, employees, customers, suppliers, lenders, the government and society (Berman et al., 1999; Harrison \& Freeman, 1999; Hillman \& Keim, 2001; Riahi-Belkaoui, 2003). Emerging management paradigms are emphasizing a stakeholder perspective (Atkinson et al., 1997; Berman et al., 1999; Harrison \& Freeman, 1999; Hillman \& Keim, 2001; Sirgy, 2002; Riahi-Belkaoui, 2003; Tangem, 2004). Moreover, an important notion revealed in many studies is that building better relations with primary stakeholders like employees, customers and suppliers could lead to increased shareholder wealth. A sustainable organizational advantage may be built with tacit assets that derive from developing relationships with key stakeholders (Hillman \& 
Keim, 2001). When studying the relationship between stakeholder management and a firm's financial performance, Berman et al. (1999) found that fostering positive connections with key stakeholders (customers and employees) can help a firm's profitability. Ultimately, it could be said that processes require financial as well as non-financial resources in order to create value for the customers (Kueng, 2000), having impact on four main groups of stakeholders: suppliers, employees, shareholders, and customers.

\section{Link between BPO and Organizational Performance}

Most organizations that have made an attempt to move toward process orientation agree that it does indeed provide numerous benefits, including cost savings through a more efficient execution of work, improved customer focus, better integration across the organization, etc. Main advantages of process-based organizational structure, in comparison to functional one, are in economical design of business processes, as well as in reducing cycle time (Sikavica \& Novak, 1999), while there is also a dramatically increased flexibility of the firm along with improved customer satisfaction. Namely, even though processes don't appear on the balance sheet as such, managers intuitively recognize that they are assets, not expenses (Keen, 1997). A key source of process benefit is improving hand-offs between functions, which can occur only when processes are broadly defined (Oden, 1999). A process orientation leads to cycle time reduction by doing a good job of coordinating work across functions. In addition, some costs are reduced with a process organization. The faster time cycles mean reduced inventories and faster receipt of cash. The reduced working capital translates into reduced costs of carrying inventory and cash. Other costs are reduced because duplication of work across functions is eliminated. A process organization eliminates such redundant activities, verifying input once for all functions (Galbraith, 2002).

Implementing BPO as a way of organizing and operating in an organization will improve internal coordination and break down the functional silos that exist in most companies. Research has shown that this increase in cooperation and decrease in conflict improve both short- and longterm performance of an organization (McCormack, Johnson and Walker, 2003). Furthermore, the more business process oriented an organization is, the better it performs both from an overall perspective as well as from the perspective of the employees.

Although along process orientation is constantly improved organizational performance mentioned, there are rare authors which have empirically investigated that relationship. Two of them are McCormack and Johnson (2001), who conducted an empirical study to explore the relationship between BPO and enhanced business performance. The research results showed that BPO is critical in reducing conflict and encouraging greater connectedness within an organization, while improving business performance. Their results indicate a surprisingly strong relationship between BPO and overall performance. Considering all the factors that can potentially affect business performance, this finding is compelling (McCormack \& Johnson, 2001).

However, experiences are showing that companies are managing their business processes with different success, what depends on established balance between organizational structure and organization's environment. In another words, not all the news about process transformation has been good. Many firms have found that even dramatic levels of process improvement often do not translate into better business performance (Keen, 1997). Furthermore, most organizations only have some of their processes well defined and are only beginning to use process measures and process management techniques to control their organizations (Harmon, 2003). All aforementioned emphasizes even more the importance of studying a process orientation as an important factor in modern business. 


\section{Research Hypotheses and Model Conceptualization}

The main purpose of this paper is to test if higher levels of business process orientation lead to better organizational performance. While a similar research has been carried out by McCormack and Johnson our contribution is the application of the link in transition economy and detailed specification of organizational performance. Since the theoretical background of the BPO and OP constructs has been presented in the first part of the paper here only the hypothesized relationships and the rational for them is presented.

As companies renovate themselves and change existing practices and adopt new ones striving to become more process oriented they inevitably optimize their processes and organizational structures that support them. There is an abundance of literature (e.g. Davenport, 1993; Hammer \& Champy, 1993; McCormack \& Johnson, 2001; Burlton, 2001; Harmon, 2003) that argues that renovation of business processes will be translated into better organizational performance. We adopt this view and based on it we present our first hypothesis:

H1: The higher the level of business process orientation a firm achieves the better it performs financially.

Becoming more process oriented has a profound impact on many facets of an organization. It changes the way employees work and interact. As functional silos are broken down and business processes start to get integrated, inter-functional conflicts decrease and inter-departmental connectedness increases. Furthermore, becoming more process oriented strengthens esprit de corps (McCormack \& Johnson, 2001) all of which has a positive effect on the satisfaction of employees. Process orientation also changes the interaction between a firm and it business partners (suppliers and customers) - by integrating processes beyond the boundaries of a firm transaction based cooperation is transformed into long-term partnership that results in increased performance for all links in a supply chain (Hendricks, Singhal, \& Stratman, 2007; Cousins \& Menguc, 2006). In this context we stipulate our second hypothesis as follows:

H2: The higher the level of business process orientation a firm achieves the better it performs non-financially in terms of more satisfied employees, customers and suppliers.

The rationale for our third hypothesis stated below is as intuitive as is widely supported in literature. Firstly, satisfied employees perform better and execute their tasks more effectively and efficiently. They are less inclined to change jobs (Karatepe et al., 2006) and are less frequently absent all of which should have a positive impact on financial performance. Satisfied customers make repeat purchases and purchase more. Good, long-term relationship with suppliers is beneficial for both parties involved (Dehning, Richardson, \& Zmud, 2004; Hendricks \& Singhal, 2003). Therefore:

\section{H3: Better non-financial performance leads to better financial performance.}

In Figure 1 the conceptualized model along with the hypothesized relationships is shown.

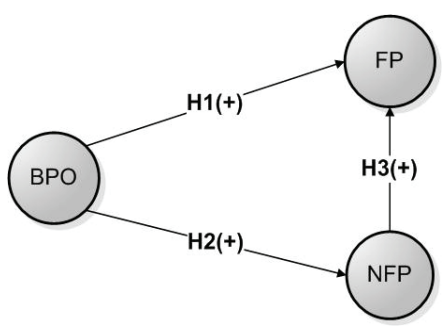

Figure 1: Conceptual model and direction of impact between constructs 
Škrinjar, Štemberger, \& Hernaus

\section{Research Methods And Data Analysis}

\section{Research Instrument}

In order to test the proposed hypotheses our instrument was composed of two parts. The first part measuring BPO was adopted from the original study conducted by McCormack and Johnson (2001). This part of the instrument was amended in two sections: (1) One question was added to the Process view section; (2) two questions were added to the Process management and measurement section. Altogether BPO construct was measured using 15 items.

Even though the original instrument from McCormack and Johnson included an overall organizational performance construct, it was only measured with two items. As our goal was to tap deeper into the problem we choose not to use this operationalization ob Organizational performance construct. Therefore we devised our own instrument for Organizational performance measurement. This represents the second part of our research instrument. Theoretically it is based on the balanced scorecard (Kaplan, Norton, 1992, 1993, 1996) and its main goal is to measure different facets of organizational performance, namely the financial and the non-financial. We used 19 items to measure the organizational performance. The basic structure and nature of the research instrument can be seen in Table 1 and Table 2 .

In addition to the latent variables measurement items some general questions for basic descriptive statistics were also included in the questionnaire.

To test the hypothesized relationships we employed the combined exploratory-confirmatory approach. In the first phase we analyzed the questionnaire items using the exploratory factor analysis in order to test if the item in fact measure pre-specified constructs. In the second phase following the approach proposed by Diamantopoulos and Siguaw (2000) we tested the relationships between constructs using the structural equation modeling.

\section{Data Collection and Sample Characteristics}

In autumn 2005, empirical data were collected through a survey of 1267 Slovenian companies that had more than 50 employees. Questionnaires were addressed to CEOs or senior managers estimated as having adequate knowledge of the BPO and performance within their companies. A total of 203 managers responded while, at the same time, 68 questionnaires were returned to the researchers with 'return to sender' (RTS) messages, indicating that the addresses were no longer valid or the companies had seized to exist. We followed the approach of Prajogo and McDermott (2005) and discounted the number of RTS mails so the final response rate was $16.9 \%$.

We originally aimed at an audience of top managers to ensure a strategic and to some degree even an interdisciplinary perspective on the company in question. Based on the criterion of the average number of employees in 2004, 36.9\% of the companies had between 50 and 249 employees, followed by $35.4 \%$ with $250-499$ employees, while $18.1 \%$ had $500-999 \%$ and $9.6 \%$ of the companies had 1000 and more employees. Given that non-profit organizations were excluded from the study, the sample is an adequate representation of the population of Slovenian companies that have more than 50 employees.

\section{Exploratory Factor Analysis}

Before testing the entire model using structural equation modeling, we have conducted exploratory factor analysis to get the first insight into our data and to assess the validity of our measurement model. The main concern in this part is "Do items really measure the specified constructs?" We used the statistical package SPSS 13.0 to run a series of data reduction tests. Data were sub- 
jected to Factor Analysis technique using principal axis factoring extraction method combined with Varimax rotation.

Firstly, we analyzed the items measuring business process orientation construct. As this construct had been tested extensively the results shown in Table 1 were anticipated. Three factors emerged each representing one aspect of BPO. Using .50 loading cut-off value, which according to Comrey and Lee (1992) is a good score, two things need to be pointed out: (1) Out of three additional items that were amended to the initial instrument, two (PROCV5 and PROCMM6) have loaded appropriately on their factor and one has not (PROCMM7) and was therefore omitted from further analysis. (2) Though two item loadings on the second factor have not reached the .50 value, we have decided to keep them in our analysis as their loading was very close to the prescribed one and have already been validated in the original study.

Table 1: Rotated factor Matrix for business process orientation

\begin{tabular}{|c|c|c|c|}
\hline & \multicolumn{3}{|c|}{ Factor } \\
\hline & 1 & 2 & 3 \\
\hline $\begin{array}{l}\text { PROCV1 - The average employee views the business as a series of } \\
\text { linked processes. }\end{array}$ & & .618 & \\
\hline $\begin{array}{l}\text { PROCV2 - Process terms such as input, output, process, and process } \\
\text { owners are used in conversation in the organization. }\end{array}$ & & .575 & \\
\hline $\begin{array}{l}\text { PROCV3 - Processes within the organization are defined and docu- } \\
\text { mented using inputs and outputs to and from our customers. }\end{array}$ & & 691 & \\
\hline $\begin{array}{l}\text { PROCV4 - The business processes are sufficiently defined so that } \\
\text { most people in the organization know how they work. }\end{array}$ & & .640 & \\
\hline $\begin{array}{l}\text { PROCV5 - Implementation of information technology is based on the } \\
\text { processes, not on functions. }\end{array}$ & & .531 & \\
\hline $\begin{array}{l}\text { PROCJ1 - Jobs are usually multidimensional and not just simple } \\
\text { tasks. }\end{array}$ & & & .469 \\
\hline PROCJ2 - Jobs include frequent problem solving. & & & .725 \\
\hline PROCJ3 - People are constantly learning new things on the job. & & & .443 \\
\hline PROCMMM1 - Process performance is measured in the organization. & .769 & & \\
\hline PROCMM2 - Process measurements are defined. & .827 & & \\
\hline PROCMM3 - Resources are allocated based on process. & .555 & & \\
\hline PROCMM4 - Specific process performance goals are in place. & .718 & & \\
\hline PROCMM5 - Process outcomes are measured. & .707 & & \\
\hline $\begin{array}{l}\text { PROCMM6 - It has been established an on-line control of information } \\
\text { quality in processes. }\end{array}$ & .598 & & \\
\hline $\begin{array}{l}\text { PROCMM7 - Information flow through process is continuous and effi- } \\
\text { cient. }\end{array}$ & .415 & & \\
\hline
\end{tabular}

Our analysis continued with the organizational performance measurement items. Closely reflecting our expectations factor analysis of OP measurement items revealed 4 factors (see Table 2). The fourth factor clearly deals with financial performance. Factors 1 (subjective measures) and 3 (objective measures) tap into non-financial performance, more precisely into employee perspective of non-financial performance. The second factor represents the customer perspective of nonfinancial performance. Considering the .50 cut-off loading value the following items were removed from the further analysis: NFEMP1, NFEMP9, NFEMP11, and NFEMP12. Even though item NFSUP did not load on its own factor, which is probably due to the fact that we only used one item for measuring the relationship with suppliers, and had loading value below .50 we decided to keep the item in further analysis as this aspect of non-financial performance is firmly grounded in theory (Freeman, 1984, 1994). 
Table 2: Rotated factor Matrix for organizational performance

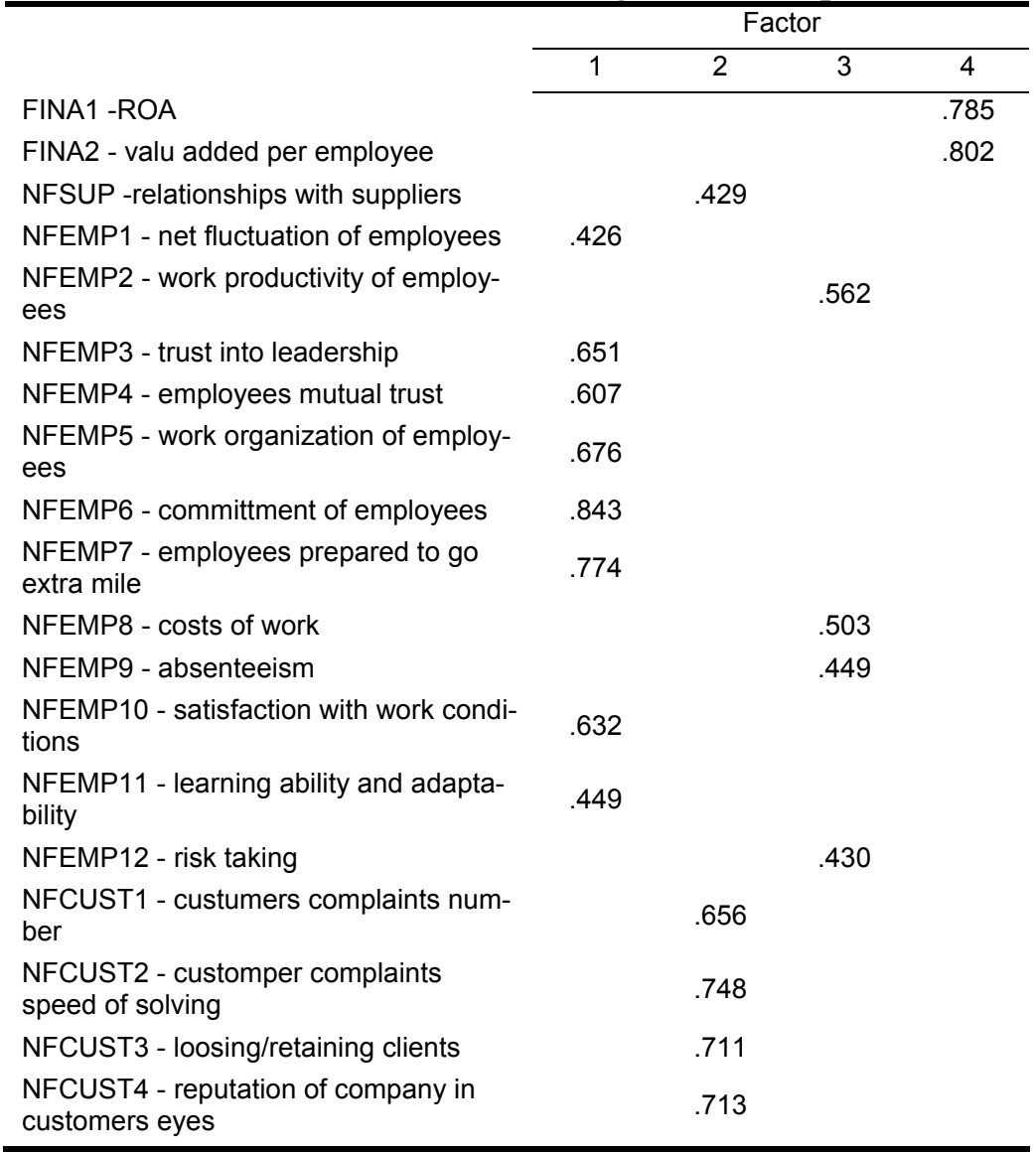

\section{Operationalization of Business Process Orientation and Organizational Performance}

After subjecting the data to factor analysis the purified data can now be used to operationalize the measurement of BPO and OP constructs. As BPO construct has already been operationalized by McCormack and Johnson we have closely followed their route and grouped items into three scales: (1) process view (PROCV) includes items PROCV1 through PROCV5; (2) process jobs (PROCJ) includes items PROCJ1 through PROCJ3; (3) process management and measurement (PROCMM) includes items PROCMM1 through PROCMM6.

Based on extensive literature review and our intention to scrutinize organizational performance in detail organizational performance is included in the model as two separate constructs: (I) financial performance (FP) and (II) non-financial performance (NFP). Construct FP is measured using FINA1 (measuring ROA) and FINA2 (value added per employee). Construct NFP is measured using items grouped into four scales: (1) NFSUP - one item (NFSUP); (2) NFEMP1 - six items (NFEMP3 through NFEMP7 and NFEMP10); (3) NFEMP2 - two items (NFEMP2 and NFEMP8); NFCUST - four items (NFCUST1 through NFCUST4).

\section{Confirmatory Analysis Using Structural Equation Modeling}

Next step in our analysis was the assessment of model fit whereby we were interested whether the hypothesized model is consistent with the data. First we examined the measurement part of the model. Our aim was to determine the validity and reliability of the measures used to represent the constructs of interest. Validity reflects the extent to which an indicator actually measures what is 
suppose to measure. The validity can be assessed by examining the magnitude and significance of the loading paths $\lambda$ that represents direct relationship between the indicator and the construct. All $\lambda$ 's should be significant (t-values should exceed 1.96) and exceed .50 threshold (Hair et al., 1998; Prajogo \& McDermot, 2005). As it can be seen from the Table 3 below all indicator loading values are significant (at $\mathrm{p}<0.01$ or better $-\mathrm{t}$-values exceed 2.64) and exceed .50 which provides validity evidence in favor of the indicators used to represent the constructs at interest.

To test the composite (construct) reliability the composite reliability index (CRI) and average variance extracted (AVE) were calculated. Composite reliability assumes that a set of latent construct indicators is consistent in the measurement (Škerlavaj et al., 2006). There is no generally acceptable standard for adequate values of CRI. Koufteros (1999) suggested values above .80, while Diamantopoulos and Siguaw (2000) were satisfied with .60. AVE is similar to CRI with the one exception that standardized loadings are squared before summing them (Hair et al., 1998; Koufteros, 1999). The cutoff value most often used for AVE is .50 (Bagozzi \& Yi, 1988; Hair et al., 1998), while there are also cases where a milder restriction of .40 was employed (Diamantopoulos and Siguaw, 2000). As it can be seen from the Table 4 all values for CRI and AVE surpass the prescribed values, therefore the reliability of indicators is acceptable.

Table 3: Unstandardized, completely standardized loading estimates and t-values

\begin{tabular}{lccc}
\hline \multicolumn{4}{c}{ LAMBDA-X } \\
\hline & $\begin{array}{c}\text { Unstandardized } \\
\text { factor loading }\end{array}$ & $\begin{array}{c}\text { Completely standardized } \\
\text { factor loading }\end{array}$ & t-value \\
\hline \multirow{2}{*}{\begin{tabular}{l} 
PROCV \\
\cline { 2 - 5 }
\end{tabular}} & 1.00 & .81 & $-^{\mathrm{a}}$ \\
\cline { 2 - 5 } & .66 & .60 & 7.60 \\
\hline
\end{tabular}

\begin{tabular}{|c|c|c|c|c|}
\hline & \multicolumn{4}{|c|}{ LAMBDA-Y } \\
\hline & & $\begin{array}{l}\text { Unstandardized } \\
\text { factor loading }\end{array}$ & $\begin{array}{l}\text { Completely standardized } \\
\text { factor loading }\end{array}$ & $\mathrm{t}$-value \\
\hline \multirow{2}{*}{$\frac{0}{2}$} & FINA1 & 1.00 & .76 & $-{ }^{a}$ \\
\hline & FINA2 & 1.28 & .96 & 8.28 \\
\hline \multirow{4}{*}{ 운 } & NEFSUP & 1.04 & .54 & 6.66 \\
\hline & NEFEM1 & 8.56 & .83 & 9.30 \\
\hline & NEFEM2 & 5.07 & .79 & 9.07 \\
\hline & NEFCUST & 1.00 & .65 & $-{ }^{a}$ \\
\hline
\end{tabular}

${ }^{a}$ Indicates a parameter fixed at 1.00 in the original solution

Table 4: Composite reliability index and average variance extracted

\begin{tabular}{ccc}
\hline & CRI & AVE \\
\hline BPO & .76 & .52 \\
FP & .86 & .75 \\
NFP & .80 & .51 \\
\hline
\end{tabular}

Before examining the hypothesized relationships the global fit of the model needs to be assessed. There is a plethora of goodness-of-fit indices that can be used as summary measures of a model's overall fit (Diamantopoulos \& Siguaw, 2000). Research evidence supports the need to use more than one index (Breckler, 1990; Bollen \& Long, 1993; Tanaka, 1993; Coenders et al., 2003). $\chi^{2}$ per degrees of freedom, comparative fit index (CFI) and nonnormed fit index (NNFI; also named the Tucker - Lewis fit index: TLI) are used most often to assess model fit (Koufteros, 1999). The ratio $\chi^{2}$ per degrees of freedom should not exceed 2, while models exhibiting CFI and NNFI indices greater than .90 have an adequate fit. Some researchers (Coenders et al., 2003) even suggest a cut-off value of .95 .

Results of fitting the model to the data show that the model had a good fit as values for all of the most frequently used indices fall within the acceptable range: $\chi^{2} / 2=2 ; \mathrm{NNFI}=.94, \mathrm{CFI}=.96$. In the Figure 2 the path diagram of our model is presented. 


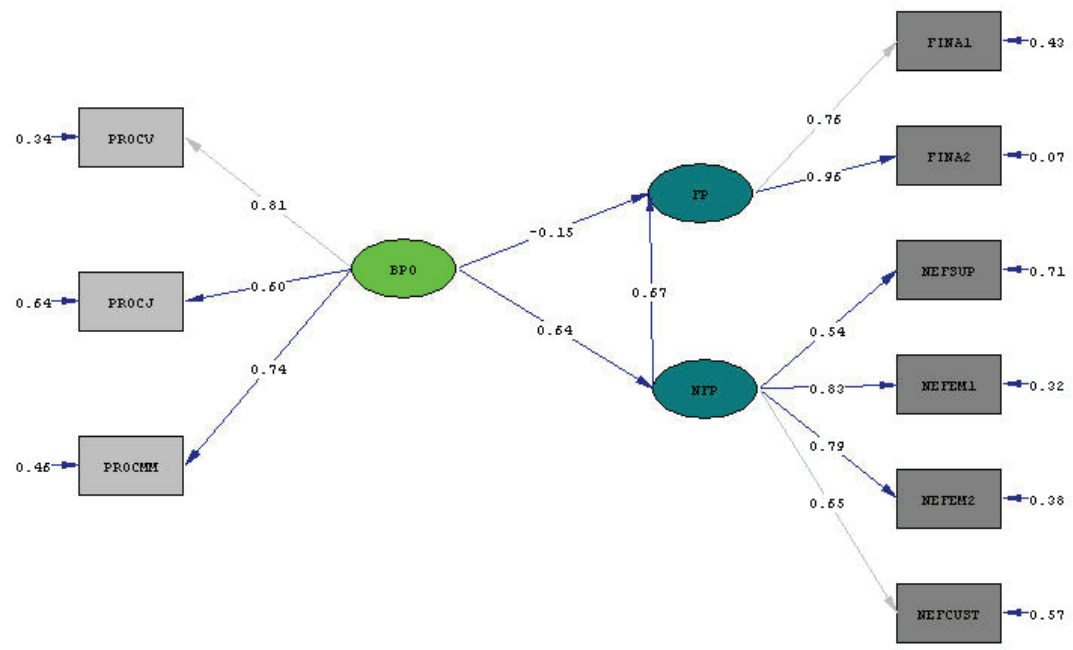

Figure 2: Path diagram of conceptualized model

As the overall model exhibited good fit the structural part can be examined. The aim is to determine whether the theoretical relationships specified by our hypotheses are indeed supported by the data. Three issues are of relevance here. First, we look if the signs of the parameters representing the paths between the constructs indicate the same direction as hypothesized. In that regard only hypotheses 2 and 3 are supported by the data as there is a positive sign between BPO and NFP and between NFP and FP. Hypotheses 1 is not supported as the direction of relationship in not as stated. Second, we examine the statistical significance of parameters. Again only paths representing second and third hypotheses were found to be statistically significant ( $\mathrm{t}$ values: 6,27 and 4,83 respectively). The relationship between BPO and FP was not found to be statistically significant. Third, the squared multiple correlations $\left(\mathrm{R}^{2}\right)$ for the structural equations are inspected as they indicate the amount of variance of endogenous constructs that is accounted for by independent constructs. For the hypotheses 2 and 3 the $\mathrm{R}^{2 \text {, }}$ s are high (.41 and .35 respectively) indicating strong relationship. Again the lack of the direct relationship as stated in hypothesis 1 was reconfirmed in very low $\mathrm{R}^{2}(.079)$ for the path representing that link.

Considering all three aspects of the structural relationship we accept the second and the third hypothesis but reject the first one.

\section{Discussion and implications}

The main goal of our study was to determine whether higher levels of business process orientation lead to better organizational performance. The data from the empirical study that has been subjected to rigorous statistical techniques has shown support for that. Therefore, based on our hypotheses we conclude that higher levels of business process orientation lead to better financial and non-financial performance. Further more it had been shown that there is a strong direct impact of BPO on non-financial performance. On the other hand no such impact has been found between BPO and financial performance. This does not mean that there is no connection whatsoever. It has been shown that BPO has strong indirect impact on financial performance through non-financial performance.

The contribution of our study is two fold: first the extension of the original study (McCormack and Johnson, 2001) whereby we have scrutinized the effects of BPO on OP in much more detail by capturing and analyzing performance in coherence with the stakeholder theory (Freeman, 1986) and balanced scorecard approach (Kaplan \& Norton, 1992, 1993, 1996). We did that by inclusion of key stakeholders (customers, employees and suppliers) in assessment of non- 
financial performance in addition to financial performance. Our conceptualization of the model therefore included two distinct yet related constructs of organizational performance. The extension of the organizational performance was made by significantly expanded measurement instrument for capturing organizational performance. This approach has proved to be useful as we were able to decompose the impact of BPO on OP and reveal the deeper structure of the relationship. Second we carried out the study in the transition economy and found that the original findings are also applicable in this socio-economic environment.

The results of our study also have many practical implications for managers. As companies renovate themselves and adopt new practices striving to attain higher levels of process orientation it enables them to improve their relationship with its key stakeholders employees, customers, and suppliers by creating a fertile environment for conducting business. Clearly such environment is also a catalyst for better financial performance. Therefore, as business environment gets more competitive business process orientation offers a way to adapt to new conditions and circumstances. Since higher business process orientation maturity levels lead to better organizational performance managers need to familiarize themselves with this concept and practical implementation issues. They need to examine their current practices, structures and management and measurement processes and assess the current state. BPO maturity model then serves as a road map for their improvement and renovation efforts.

Though we rejected the first hypotheses postulating the positive effect of BPO on financial performance this of course is not conclusive. The lack of significant effect might be due to time lag in the effects. Clearly organizational renovation and process improvement practices cannot and do not happen instantaneously but take a lot of time. Financial results of such efforts might not arise immediately. This points to one limitation of our research, namely the study has not been devised in a longitudinal nature. Therefore, time lag in effects cannot be detected. This dimension is left for future research. On the agenda for future work is also the inclusion of Croatian companies in the model in order to extend the applicability of the findings. For analyzing time lag in effects and for gaining wider generalization ability the study will be repeated in Slovenia and Croatia and extended to new countries.

\section{References}

Andersson, P., Aronsson, H., \& Storhagen, N. G. (1989). Measuring logistics performance. Engineering Costs and Production Economics, 17, 253-262.

Atkinson, A. A., Waterhouse, J. H., \& Wells, R. B. (1997). A stakeholder approach to strategic performance measurement. Sloan Management Review, 38, 25-37.

Bagozzi, R.P., \& Yi, Y. (1988). On the evaluation of structural equation models. Academy of Marketing Science, 16 (1), 74-94.

Berman, S. L., Wicks, A. C., Kotha, S., \& Jones, T. M. (1999). Does stakeholder orientation matter? The relationship between stakeholder management models and a firm financial performance. Academy of Management Journal, 42(5), 488-506.

Bollen, K.A. \& Long, J.S. (1993). Testing structural equation models. Newbury Park, CA: Sage.

Breckler, S.J. (1990). Applications of covariance structural modeling in psychology: cause for concern? Psychological Bulletin, 107 (23), 260-273.

Burlton, R.T. (2001). Business process management: Profiting from process. Indianapolis: Sams.

Coenders, G., Casa, F., Figuer, C., \& Gonzalez, M. (2003). Relationship between parents' and children's values and children's overall life satisfaction-A comparison across countries. Frankfurt am Main: 5th Conference of the International Society for Quality-of-Life Studies, Johan Wolfgang GoetheUniversity. 
Comrey, A.L. \& Lee, H.B. (1992). A first course in factor analysis ( ${ }^{\text {nd }}$ ed.). Hillsdale, NJ: Lawrence Erlbaum Associates.

Cousins, P. D. \& Menguc, B. (2006). The implications of socialization and integration in supply chain management. Journal of Operations Management, 24, 604-620

Daft, R. L. (2004). Organization theory and design. Mason, Ohio: Thompson.

Davenport, T.H. (1993). Process innovation: Reengineering work through information technology. Boston: Harvard Business School Press.

Dehning, B., Richardson, V.J., \& Zmud, R.W. (2004). The financial performance effects of IT-based supply chain management systems in manufacturing firms. Working Paper. Argyros School of Business and Economics, Chapman University, California.

Diamantopoulos, A. \& Siguaw, J.A. (2000). Introducing LISREL. London: Sage Publications.

Eccles. (1991). The performance measurement manifesto. Harvard Business Review, 69(1), 131-137.

Freeman, E. R. (1984). Strategic management - A stakeholder approach. London: Pitman.

Freeman, E. R. (1994). Politics of stakeholder theory: Some future directions. Business Ethics Quarterly, 4, 409-422.

Galbraith, J. R. (2002). Designing organizations: An executive guide to strategy, structure, and process. San Francisco: Jossey-Bass.

Häggström, C. \& Oscarsson, K. (2001). Making companies more efficient by process orientation-Describing and mapping business processes, Master Thesis, Chalmers University of Technology \& Royal Institute of Technology, Göteborg/Stockholm

Hair, J.F., Anderson, R.E., Tatham, R.L., \& Black, W.C. (1998). Multivariate data analysis (5th ed.). London, UK: Prentice-Hall.

Hammer, M.H., \& Champy, J. (1993). Reengineering the corporation: A manifesto for business evolution. New York.: Harper Business

Hammer, M., \& Stanton, S. (2001). How process enterprises really work. Harvard Business Review, 77(6), $108-118$.

Harmon, P. (2003). Business process change: A manager's guide to improving, redesigning, and automating processes. San Francisco: Morgan Kaufmann Publishers.

Harrison, J. S., \& Freeman, J. S. (1999). Stakeholders, social responsibility, and performance: empirical evidence and theoretical perspectives. Academy of Management Journal, 42, 479-485.

Hendricks, K. B., Singhal, V. R., Stratman, J. K. (2007). The impact of enterprise systems on corporate performance: A study of ERP, SCM, and CRM system implementations. Journal of Operations Management, $25,65-82$

Hendricks, K.B., \& Singhal, V.R. (2003). The effect of supply chain glitches on shareholder value. Journal of Operations Management, 21, 501-522.

Hillman, A. J., \& Keim, G. D. (2001). Shareholder value, stakeholder management, and social issues: What's the bottom line? Strategic Management Journal, 22(2), 125.

Kai, S. A. (1999). Organizational change and information technology. Doctoral dissertation, Göteborg University, Göteborg

Kaplan, R.S., \& Norton, D.P. (1992). The balanced scorecard - Measures that drive performance. Harvard Business Review, 70(1), 71-79.

Kaplan, R.S., \& Norton, D.P. (1993). Putting the balanced scorecard to work. Harvard Business Review 9/10, 134-147. 
Impact of Business Process Orientation

Kaplan, R.S., \& Norton, D.P. (1996). Using the balanced scorecard as strategic management system. Harvard Business Review, 1/2, 75-85.

Karatepe, O.M., Uludag, O., Menevis, I., Hadzimehmedagic, L., \& Baddar, L. (2006). The effects of selected individual characteristics on frontline employee performance and job satisfaction. Tourism Management, 27, 547-560.

Keen, P. G. W. (1997). The process edge-Creating value where it counts. Boston: Harvard Business School Press.

Koufteros, X.A. (1999). Testing a model of pull production: A paradigm for manufacturing research using structural equation modeling. Journal of Operations Management, 17, 467-488.

Kueng, P. (2000). Process performance measurement system: A tool to support process-based organizations. Total Quality Management, 11(1), 67-85.

Levi, M. H. (2002). The business process (quiet) revolution: Transformation to process organization. Interfacing Technologies Corporation. Retrieved from http://www.interfacing.com/rtecontent/document/CreatingProcessOrganization03.pdf

Lindfors, C. (2003). Process orientation: An approach for organizations to function effectively. Retrieved from http://cic.vtt.fi/lean/singapore/LindforsFinal.pdf

Lockamy III, A., \& McCormack, K. (2004). The development of a supply chain management process maturity model using the concepts of business process orientation. Supply Chain Management: An International Journal, 9(4), 272-278.

Lynch \& Cross (1991), Measure up - The essential guide to measuring business performance. London: Mandarin.

McCormack, K. (2003). Benchmarking using the BPO Maturity Model. BPM Opinions Series. Retrieved from http://www.bpmresources.com

McCormack, K. P., \& Johnson, W. C. (2001). Business process orientation - Gaining the e-business competitive advantage. Florida: St. Lucie Press.

McCormack, K. P., Johnson, W. C., \& Walker, W. T. (2003). Supply chain networks and business process orientation. Florida: St. Lucie Press.

Najmi, M., Rigas, J., \& Fan, I. (2005). A framework to review performance measurement systems. Business Process Management Journal, 11(2), 109-122.

Oden, H. W. (1999). Transforming the organization: A social-technical approach. Westport: Quorum books.

O'Hanlon, T. (2003). Process landscapes. Retrieved from http://saferpak.com/process manage articles/Process\%20Landscapes.pdf

Prajogo, D.I., \& McDermott, C.M., (2005). The relationship between total quality management practices and organizational culture. International Journal of Operations and Production Management, 25, $1101-1122$.

Riahi-Belkaoui, A. (2003). Intellectual capital and firm performance of US multinational firms - a study of the resource-based and stakeholder views. Journal of Intellectual Capital, 4(2), 215-226.

Sikavica, P., \& Novak, M. (1999). Poslovna organizacija, Informator, Zagreb.

Sirgy, J. M. (2002). Measuring corporate performance by building on the stakeholder model of business ethics. Journal of Business Ethics, 35(3), 143-162.

Spanyi, A. (2004a). Six Sigma and business process management. BPM Group. Retrieved from http://www.spanyi.com

Spanyi, A. (2004b). Towards process competence. BPM Group. Retrieved from http://www.spanyi.com 
Škerlavaj, M., Indihar Štemberger, M., Škrinjar, R., \& Dimovski, V. (2006). Organizational learning culture- The missing link between business process change and organizational performance. International Journal of Production Economics, 10, 1016.

Tanaka, J.S. (1993). Multifaceted conception of fit in structural equation models. Newbury Park, CA: Sage.

Tangem, S. (2004). Performance measurement: From philosophy to practice. International Journal of Productivity and Performance Management, 53(8), 726-737.

Tenner, A. R., \& DeToro, I. J. (1996). Process redesign: The implementation guide for managers. New Jersey: Prentice Hall.

zur Muehlen, M. (2002). Workflow-based process controlling. Berlin: Logos Verlag.

\section{Biographies}

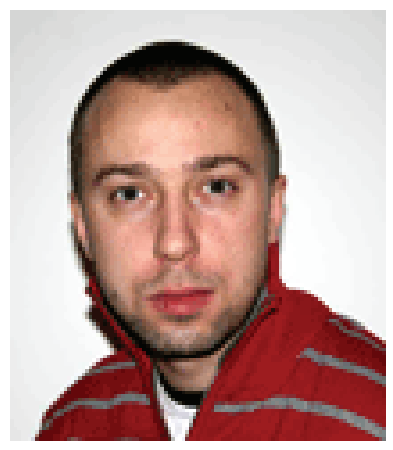

Rok Škrinjar is a teaching assistant at the Faculty of Economics, University of Ljubljana, Slovenia. His research interests include business process renovation and business process management and their impact on organizational performance. He has published several scientific and professional papers on this subject. In addition to being the teaching assistant for several undergraduate courses he works on consulting projects in the area of business process renovation.

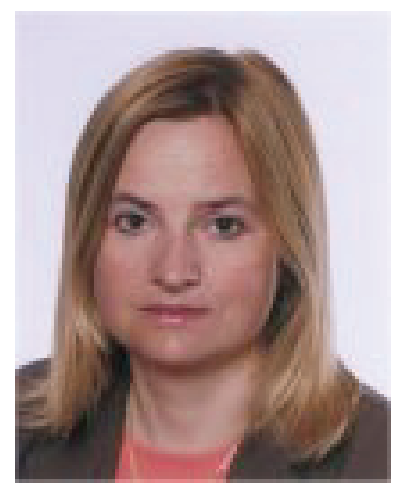

Mojca Indihar Stemberger is an associate professor of information management at the Faculty of Economics, University of Ljubljana, Slovenia. Her research interests include business process renovation, ebusiness and decision support systems. She received her Master in Computer and Information Science degree in 1996, and her Ph.D. in Information Science in 2000 from the University of Ljubljana. Dr. Indihar Stemberger has published several scientific and professional papers in Slovenia and abroad. She has been a consultant for business process change on several projects in public and private sector. From 2001 she has been a president of Slovene information management conference and she is a conference chair of InSITE 2007 conference.

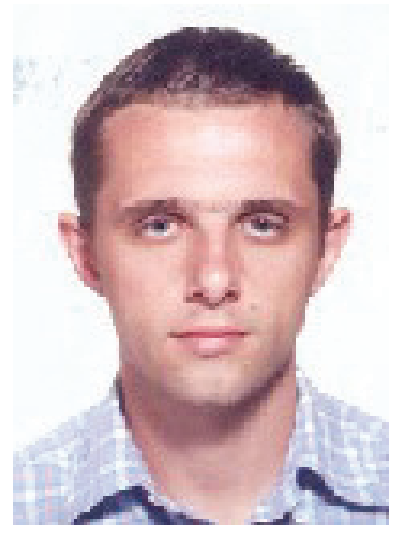

Tomislav Hernaus is a research and teaching assistant of organisational theory and business process management at the Faculty of Economics and Business, University of Zagreb (Croatia),. In 2006 he received his Master degree in Organisation Sciences from the University of Zagreb with the topic of thesis "Transformation of Classical Organisation toward Process-based Organisation". His research interests are: organisation design, organisation theory, organisation development, and business process management. He is an author and co-author of several scientific articles and co-author on several projects in public sector. 